\title{
What guides information consensus? Approaching the reduction of equivocality in process innovations
}

\section{Erik Flores-García*, Jessica Bruch, Magnus Wiktorsson and Mats Jackson}

\author{
School of Innovation, Design, and Engineering, \\ Mälardalen University, \\ P.O. Box 325, \\ SE-631 05 Eskilstuna, Sweden \\ Email: erik.flores@mdh.se \\ *Corresponding author
}

\begin{abstract}
This study investigates the achievement of information consensus and the reduction of equivocality in process innovations. Drawing on the operations management literature, a new framework to guide information consensus in the reduction of equivocality in process innovations is proposed. The analysis is based on a real-time case study in the heavy vehicle industry. The results show that information consensus is not achieved by a single event, but active work towards this goal is necessary, and a clear set of pre-requisites is needed for achieving information consensus. The concepts of strategic objective, decision areas, and external and internal fit are identified as pre-requisites for achieving information consensus about the purpose, characteristics, and functionalities of process innovations.
\end{abstract}

[Submitted 28 February 2018; Accepted 18 March 2019]

Keywords: production; process innovation; case study; equivocality; strategic objective; decision area; external fit; internal fit; uncertainty.

Reference to this paper should be made as follows: Flores-García, E., Bruch, J., Wiktorsson, M. and Jackson, M. (2020) 'What guides information consensus? Approaching the reduction of equivocality in process innovations', Int. J. Manufacturing Research, Vol. 15, No. 1, pp.73-89.

Biographical notes: Erik Flores-García is a $\mathrm{PhD}$ candidate at the Innofacture Industrial Graduate School, Mälardalen University. His research interests include discrete event simulation, production decisions and process innovations.

Jessica Bruch is a Professor of Production Systems at the Department of Product Realization at Mälardalen University. Her research interest concerns various aspects of production development and addresses both technological and organisational aspects of projects, companies, and inter-organisational level.

Magnus Wiktorsson is a Professor of Production Logistics at the Royal Institute of Technology (KTH). His research interest concerns how complex production logistic systems can be described and predicted. The application areas are within the manufacturing sector and his research is based on a strong systemic and mathematical interest. 
Mats Jackson is a Professor of Production Systems and is currently the Dean of Research at Jönköping University. His research interests concern operations management and design of production systems.

This paper is a revised and expanded version of a paper entitled 'Towards a reduction of uncertainty in production system design decisions' presented at The Swedish Production Symposium, Lund, Sweden, 25-27 October 2016.

\section{Introduction}

Research widely recognises that uncertainties in the introduction of process innovations threaten the competitiveness of production systems (Gaubinger et al., 2014; O'Connor and Rice, 2013; Liu and Hart, 2011). In particular, the literature shows that high levels of uncertainty in process innovations lead to technical difficulties, cost overruns, and missed market opportunities (Chemarin and Orset, 2011). Prior studies emphasise the importance of reducing uncertainty in novel production technologies or organisational processes (Harris and Woolley, 2009; Tatikonda and Montoya-Weiss, 2001). In particular, recent publications highlight the need for studies analysing multiple and conflicting interpretations, namely, equivocality, in the introduction of process innovations (Parida et al., 2017).

Prior studies on equivocality focus on understanding its consequences or the strategies that may lead to its reduction (Sjödin et al., 2016; Stevens, 2014; Eriksson et al., 2016). However, the existing research does not clarify what guides information consensus. This issue is critical because equivocality originates from a lack of consensus and understanding (Eriksson et al., 2016). Thus, managers may fail to commit to decisions, or make failed choices, when information consensus is lacking (Ramasesh and Browning, 2014; Bruch and Bellgran, 2013). Therefore, understanding information consensus is essential to avoid impulsive, uncoordinated, and ineffective decisions when introducing process innovations (Bryan and Farrell, 2008; Reichstein and Salter, 2006).

The purpose of this study is to analyse information consensus and the reduction of equivocality in process innovations. Acknowledging the importance of decisions when novel production technologies or organisational processes are introduced (Säfsten et al., 2014; Porter, 1985), this study draws on a decision perspective from the operations management literature to identify the pre-requisites that guide information consensus in the reduction of equivocality in process innovations. To this end, a case study involving the introduction of process innovations at a heavy vehicle manufacturer is carried out. The results of this study offer several novel contributions. First, a new framework is proposed to guide information consensus in process innovations. The proposed framework addresses the lack of tools required by modern-day production systems to deal with equivocality in the presence of high rates of technological change and competitiveness (Frishammar et al., 2011; Yin et al., 2017). Second, this study identifies the concepts of strategic objective, decision areas, and external and internal fit as pre-requisites that guide information consensus in process innovations. This finding may help managers oversee activities that target the reduction of equivocality and understand how these activities align with the different functions of a manufacturing company. 
Finally, this study indicates that information consensus requires continuous work in the design phase of a production system, and a clear set of pre-requisites that facilitate the achievement of information consensus is needed. This finding may help identify activities that lead to establishing novel production technologies or organisational processes (Milewski et al., 2015).

\section{Frame of reference}

\subsection{Developing an understanding of equivocality in process innovations}

Process innovations involve the introduction of new or substantially improved elements in the production processes. These may include new equipment, material, or reengineering of operational processes characterised by an internal organisational focus (Marzi et al., 2017; Piening and Salge, 2015). Process innovations are different from small-scale adjustments in production and consist of broad changes aimed at increasing competitiveness (Milewski et al., 2015; Pisano, 1997). Managing these changes is not simple. Therefore, the literature prescribes the introduction of process innovations in the design phase of a production system. Production system design consists of the conception and planning of activities focused on introducing new elements in a production system (Bellgran and Säfsten, 2010; Gino and Pisano, 2008). Despite these recommendations, uncertainty and equivocality jeopardise process innovations (Parida et al., 2017; Sjödin et al., 2016; Frishammar et al., 2011). Equivocality and uncertainty affect companies that introduce novel production technologies or organisational processes, different from current practices. In these cases, staff possess no information or are unable to reach consensus about the information that may help move the design of a production system forward (Jalonen, 2011; Doraszelski, 2004; Montoya-Weiss and O’Driscoll, 2000).

The current understanding of uncertainty and equivocality is rooted in contingency theory, which explains how organisations process information. In this context, uncertainty is interpreted as the difference of information necessary to complete a task (Galbraith, 1973). Activities that may lead to a reduction of uncertainty focus on the acquisition of additional information (Koufteros et al., 2005). Equivocality concerns the existence of multiple and conflicting interpretations adopted by a group of individuals (Daft and Macintosh, 1981; Zack, 2001). Process innovations are especially problematic in terms of equivocality because staff members frequently possess insufficient information and rely on imprecise propositions to make decisions (Stevens, 2014; Frishammar et al., 2011). Prior studies suggest that the reduction of equivocality should not focus on the increase or accuracy of information but instead concentrate on guiding future actions (Sutcliffe, 1994; Frishammar et al., 2011). A key factor to reduce equivocality is achieving information consensus (Daft and Weick, 1984; Weick, 1995). This requires the exchange of subjective views to define a problem, resolve disagreements, and enact a reasonable interpretation to move forward (Daft and Lengel, 1986). Staff may reduce equivocality by sharing a point of reference that is common to all functions involved in process innovation. For example, Sjödin et al. (2016) propose joint problem-solving activities that promote the shared meaning and interpretation of information, collaborative work, and collective setting of goals in process innovations. 


\subsection{The importance of a decision approach}

Prior research shows that decisions made during the development of process innovations require information consensus to identify opportunities and threats to increased competitiveness (Frishammar, 2003; Stock and Tatikonda, 2008). Therefore, a decision approach should be considered to understand information consensus in process innovations. This approach builds on the operations management literature and regards a decision as a point of reference for the commitment of actions and resources across different departments of a manufacturing company (Mintzberg et al., 1976). From this perspective, decisions determine the purpose of changes in a production system and specify what a production system will look like and how it will operate (Hayes et al., 2004). To gain insight into a decision perspective and its implications on information consensus, this study relies on four classical concepts that underpin the tenets of operations management: strategic objectives, decision areas, external fit, and internal fit.

The strategic objective concept defines the purpose of introducing new production technologies or organisational processes. This concept argues that configuring a production system inevitably involves trade-offs (Skinner, 1969). Therefore, manufacturing companies require strategic objectives that prioritise a limited number of tasks to achieve a competitive advantage (Ward et al., 2007). Strategic objectives include clearly defined goals that rank overall competitiveness higher than local solutions (Machuca et al., 2011; Petrick and Provance, 2005). Measures including cost, quality, flexibility, and delivery commonly specify the strategic objectives of manufacturing organisations (Slack and Lewis, 2002; Olhager, 1993; Berry et al., 1991).

The concept of decision areas defines the configuration of a production system and represents the set of choices that determine what a production system will look like (Choudhari et al., 2010; Díaz Garrido et al., 2007). Decision areas are essential to production systems because choices in this domain influence the strategic objectives and competitiveness of a manufacturing company (Miltenburg, 2005; Soosay et al., 2016). In addition, firms that actively consider how to organise production based on these decisions show better performance (Reichstein and Salter, 2006; Pisano, 1997). Decision areas are grouped into structural and infrastructural categories (Hayes and Wheelwright, 1984). Structural decision areas consider the long-term impact of choices and involve major capital investments. Decisions belonging to infrastructural categories often are of a tactical nature, arise from a decision-making process, and demand minor investments.

The concept of external fit requires that manufacturing companies match their decisions with external settings. Conversely, internal fit requires that decisions made about different parts of a production system are mutually supportive (Choudhari et al., 2010; Nair and Boulton, 2008). When introducing new production technologies and organisational processes, the external and internal fit determine the capabilities of a production system and its relationship with customers and markets (Miller, 1992). Research argues that alignment between external and internal fit is necessary to achieve competitiveness (Bates et al., 1995; Sun and Hong, 2002). According to da Silveira (2005), decisions involving external fit comprise product range, customer order size, and level of schedule changes, while choices regarding internal fit relate to production processes, production volumes, and key manufacturing tasks. 


\section{Method}

\subsection{Research design}

This study investigates all factors considered important by managers when guiding information consensus in process innovations. The present analysis is based on the case study methodology. This choice is explained by the need to conduct research in a real-life setting with a lack of control over behaviours (Voss et al., 2002; Yin, 2013). The case study methodology is also suitable to identify circumstances, such as pre-requisites, that appear to influence information consensus as these are empirically discovered during data collection (McCutcheon and Meredith, 1993). Prior studies suggest that manufacturing companies reduce equivocality over time (Sjödin et al., 2016). Therefore, this study selected a real-time approach that allowed the investigation of information consensus over multiple points in time (Karlsson, 2010). The selection of the case was based on two criteria. First, we focused on manufacturing companies with a tradition of successfully introducing process innovations. Second, we selected a case where process innovations included novel production technologies or organisational processes aimed at increasing competitiveness. This study limited its data collection and analysis to the design of a production system. The rationale behind this choice relates to prior studies showing that equivocality is present and information consensus achieved in the production system design phase (Milewski et al., 2015; Frishammar et al., 2011).

\subsection{Data collection and analysis}

Data collection was carried out between February and May 2016. Our investigation followed five phases established by the selected manufacturing company to introduce a process innovation. These phases included the definition of process innovation objectives, analysis of the existing production system, comparison between process innovation objectives and the capabilities of the current production system, process innovation development, and process innovation prototyping.

The analysis began by familiarising with the case. The first author gained access to managers supporting process innovation in the chosen company. These managers described the activities, personnel, objectives, and concerns of the case. This initial dialogue helped identify the key members of the organisation responsible for process innovation. The authors selected five key members based on the diversity of backgrounds and responsibilities. These included a manufacturing engineering manager, multi-product assembly system concept owner, project leader, logistics developer, and a manufacturing engineer. The first author conducted individual semi-structured interviews with these key company members. All interviews began with an open discussion about the respondents' background and an opportunity to express observations about the process innovation. Then, the interviewees provided a detailed description of the objectives and characteristics of the process innovations and identified the decisions of importance to its implementation. Finally, the interviewees described the uncertainty and equivocality encountered in the introduction of process innovation and how uncertainty and equivocality were resolved. The interviews lasted between 50 and 64 minutes. The first author transcribed all interviews. Afterwards, interviewees were contacted at a later date 
for further clarification to increase the authors' understanding about the case. Additional information was collected after the manufacturing company granted the first author access to company documents detailing the goals, activities, time plans, best practices, findings, risk analysis, and next steps.

In this phase, the authors focused on understanding the impact that the strategic objective, decision areas, external fit, and internal fit concepts had on information consensus and the consequent reduction of equivocality in process innovations. This step began by reflecting on interview data and was followed by a series of face-to-face discussions with each interviewee. The purpose of these meetings was gaining richer insight and further clarifying responses. Then, the first author collected additional data through field notes collected in ten one-hour meetings held during ten weeks and three full-day workshops involving all company members that participated in the design of the production system. The purpose of participating in these meetings was to collect evidence from additional participants, including manufacturing site managers and members of a cross-functional team responsible for the process innovation. In addition, this served to eliminate unsubstantiated elements, cross-check previously acquired data, and identify alternative explanations about information consensus. The data were, then, compared to identify relationships, patterns, and differences, as suggested by Miles et al. (2013). The authors gathered the preliminary findings in a spreadsheet database and concurrently compared the findings from the existing literature with the newly collected data. The analysis aimed at identifying what guided consensus in situations of equivocality. A set of categories emerged from this analysis. Then, the collected data and findings obtained from the literature were organised according to these categories. The differences between these two datasets allowed the authors to draft an initial framework. This framework was refined through constant comparison between the newly collected data and findings from the literature.

\section{Empirical findings}

\subsection{Case description}

To investigate information consensus in a context of process innovation, we selected a global manufacturing company focused on the production of construction equipment. This industry is characterised by highly specialised products that are individually configured according to customer needs and grouped into families that target a specific market. Traditionally, this classification of product families serves not only to distinguish a manufacturing company's product offering but also to segment the assembly of products. Therefore, production systems in this industry are distinguished by assembly lines that specialise in a single product family and share little other than the same manufacturing facility. Furthermore, all products are manually assembled by experienced and skilled personnel, and planned production volumes are moderate.

In 2016, the company of interest selected one of its manufacturing sites in Sweden to deploy a global initiative. This aimed to introduce new production technologies and organisational processes that would enable the assembly of more than one product family in an assembly line. The case company considered this initiative a process innovation because of the broad scope of changes affecting the production system, the novelty of its approach when compared to traditional production, the lack of experience necessary for 
its conception, and the large number of unknown factors in its development. Considerable resources were deployed. In addition, all conception and planning of the process innovation would be handled by a cross-disciplinary team of 15 global experts and personnel from the Swedish site including managers and production experts. The next sections present how information consensus was achieved in the five phases of process innovation development at the manufacturing company.

\subsection{Process innovation objectives}

This phase was characterised by multiple and conflicting interpretations about the available information. Initially, two perspectives were present. On the one hand, company members experienced a lack of understanding about how to proceed and what information to collect. On the other hand, they showed lack of trust in an initial idea upon which to move forward but the certainty that all necessary information was present. Representative quotes showing the lack of information consensus are reported in Table 1.

Despite these differences, participants pointed out the need for information consensus. This was confirmed by the manufacturing engineering manager, who, after an initial meeting, stated “we don't have the same view, but we need to set a starting point. The most important issue is to have a shared understanding of why we do this (process innovation), and that this is shared from management to every operator". A full day workshop was held to facilitate information consensus and abridge these two perspectives.

Table 1 Lack of information consensus at the beginning of the case

\begin{tabular}{|c|c|}
\hline Function & Representative quote \\
\hline \multicolumn{2}{|r|}{ Lack of understanding on how to proceed and what information to collect } \\
\hline $\begin{array}{l}\text { Manufacturing } \\
\text { engineering } \\
\text { manager }\end{array}$ & $\begin{array}{l}\text { "We need to reform... that is one thing we have as a target to change. As I have } \\
\text { said many times, to do the physical changes in the workshop that is not the } \\
\text { biggest issue. The challenge is everything around to support and improve our } \\
\text { operators and assembly. How will it work? I am a bit worried about that. What } \\
\text { kind of information will be needed?" }\end{array}$ \\
\hline $\begin{array}{l}\text { Logistics } \\
\text { developer }\end{array}$ & $\begin{array}{l}\text { "We have to make sure we chose the right thing. This is new to us. We are not } \\
\text { experts in this area. We have to see how it will fit when you put it into the daily } \\
\text { routine of actually introducing it to the working space." }\end{array}$ \\
\hline $\begin{array}{l}\text { Manufacturing } \\
\text { engineer }\end{array}$ & $\begin{array}{l}\text { "It's not only about the pieces, it's the system around you, and finding the right } \\
\text { solution for you." }\end{array}$ \\
\hline Concept owner & $\begin{array}{l}\text { "You can do it in a lot of ways and still get the same result. What should we } \\
\text { choose? That's a tricky one. What should we do? What is complying with the } \\
\text { concept? How do we measure if it is concept compliant or not?" }\end{array}$ \\
\hline
\end{tabular}

Lack of trust in an initial idea, but certainty that all necessary information was present

Project leader "I think we have all the information we need, we have all the information in the system"

The purpose of this workshop was defining the objectives and outcome of the process innovation. This was perceived as a crucial first step, as stated by one of the workshop participants: "we need to agree on what is important for us to see a new solution and its possibilities". The workshop began with a discussion over the set of corporate objectives established by the manufacturing site. These objectives were considered too general. 
Significant effort was devoted to developing an objective that met corporate needs and could be communicated throughout the manufacturing site. Once developed, this objective could not be distinguished from an early draft of what the process innovation outcome would look like.

\subsection{Analysis of existing production system}

The second phase involved the analysis of the existing production system. The relationship between information consensus and this phase of process innovation is best explained by the site manager, "we see this (process innovation) as an improvement to our current factory. We need a base to understand what we can reach, and this study (of the existing production system) is that base". The outcome of the existing production system analysis was essential for achieving information consensus because, as stated by the project leader, "it provides the base information. A starting point for different departments to discuss". Initially, this analysis aimed to include all aspects of the existing production system. However, the analysis gradually shifted its attention to two salient issues: the production processes and the market affecting the production process. When inquired about the reasons behind this revision, the concept owner revealed that "we need our analysis to align with the objectives (of the process innovation)... We are worried about two issues: how to produce different product families in one assembly line and how will market changes affect assembly". The criticality of these issues was increased by the absence of a general understanding of the existing production system. This was a consequence of a prior focus on independently developing and improving each assembly line. Meetings were held on a weekly basis and were focused on understanding product and market concerns from a general perspective. The analysis of the existing production system relied on simplifications to understand the operation of the production system. Case participants agreed that simplifications were needed since a high level of detail would be resource consuming, and the amount of information overwhelming.

\subsection{Process innovation objectives vs. current capabilities}

This phase compared the simplified result of the production system analysis to the objectives of the process innovation. This stage was particularly relevant to the process innovation outcome and information consensus because the development team agreed on the critical issues to be addressed in the development of the process innovation. Accomplishing information consensus was not simple, as shown by the representative quotes reported in Table 2 .

To reduce the differences in perspectives and guide information consensus, the development team visualised the existing production system as a starting point and the process innovation objective as a finish line. The space in between these ends was defined by what the manufacturing engineering manager called the principles of our production system. This contained the critical issues that determined what and how a production system would produce before and after the introduction of the process innovation. Lively discussions, numerous weekly meetings, and a full-day workshop were required to achieve information consensus on these critical issues. 
Table 2 The challenge of achieving information consensus in workshop 2

\begin{tabular}{ll}
\hline Function & \multicolumn{1}{c}{ Representative quote } \\
\hline $\begin{array}{l}\text { Manufacturing } \\
\text { engineer }\end{array}$ & $\begin{array}{l}\text { "We need to stop and see to come to an agreement. A lot of thinking is } \\
\text { important, and it takes time." }\end{array}$ \\
Project leader & "We should get to an agreement about this (information). It is important to \\
& $\begin{array}{l}\text { see the same problem, the same solution, and the same way forward. We } \\
\text { need to discuss together." } \\
\text { "To come to an agreement we need to make a package that we can all } \\
\text { understand. This is tricky. To find the right information the key is to get } \\
\text { people to talk. Talk freely, leave their comfort zone, and think about what } \\
\text { is possible." }\end{array}$ \\
\hline
\end{tabular}

\subsection{Process innovation development and prototyping}

The phase of process innovation development and prototyping concentrated on activities that detailed how the process innovation would operate. These activities were guided by the result on information consensus from previous phases. The largest allocation of time, resources, and activities to the process innovation occurred in this phase. A final workshop was held to present the prototyped process innovation and the result so far achieved. Information consensus in process innovation development and prototyping was limited to discussions held in this final workshop. Concerns were raised about how current quality issues in assembly would affect the process innovation and the need to modify the existing IT system to coordinate production planning in the process innovation. Table 3 presents the information consensus achieved in different phases.

Table 3 Information consensus at each phase during the case

Phase of process innovation at manufacturing company

Process innovation objectives

Analysis of existing production system

Process innovation objectives vs. current capabilities

Process innovation development and prototyping

\section{Result of information consensus}

Shortening lead time to customers, reducing manufacturing footprint, providing a common architecture for all products, and facilitating the use of shared technologies

Single assembly line capable of producing the three existing product families on site with their 600 variants. Yearly volume and takt time established

Assembly sequence, main line and sub-assembly processes, operations per station, handling product variation

Changes in product demand

Adapting current logistics

Supporting competence development through training, and work instruction improvement

Worker assignment in assembly and meeting takt

Effects of new product design and current product design changes

Assessment of process innovation benefits

Length of assembly stations

Addressing quality issues

Developing IT system 


\section{Discussion}

Prior findings show that the introduction of process innovations is a challenging task (Piening and Salge, 2015; Reichstein and Salter, 2006). This difficulty is increased by the presence of multiple and conflicting interpretations, namely, equivocality about information due to novel production technologies or organisational processes. The results of this study indicate that the concepts of strategic objective, decision areas, external fit, and internal fit may guide information consensus through the exchange of subjective views that define the purpose, characteristics, and operation of process innovation. This result is critical for theoretical and practical implications, because it confirms the importance of information consensus in the reduction of equivocality (Eriksson et al., 2016; Daft and Lengel, 1986). By specifying what matters for guiding information consensus, this study contributes to prior findings that have determined the content of activities leading to the successful introduction of novel production technologies or organisational processes (Sjödin et al., 2016; Milewski et al., 2015; Kurkkio et al., 2011).

Table 4 Framework guiding information consensus for the reduction of equivocality in process innovations

\begin{tabular}{lll}
\hline Concept & \multicolumn{1}{c}{ Description } & \multicolumn{1}{c}{ Information consensus } \\
\hline $\begin{array}{l}\text { Strategic } \\
\text { objective }\end{array}$ & $\begin{array}{l}\text { Inherent strengths pursued by a } \\
\text { manufacturing company }\end{array}$ & Cost, quality, flexibility, delivery \\
$\begin{array}{l}\text { Decision } \\
\text { areas }\end{array}$ & $\begin{array}{l}\text { Decisions that determine the } \\
\text { internal composition of a } \\
\text { manufacturing company }\end{array}$ & $\begin{array}{l}\text { Structural decisions } \\
\text { Process technology } \\
\text { Capacity }\end{array}$ \\
& & Facilities \\
& & Vertical integration \\
& & Infrastructural decisions \\
& & Human resources \\
& & Organisation \\
& & Quality \\
& & Production planning \\
External & Congruence between decisions & Product range, customer order size, level of schedule \\
fit & made in a production system & changes \\
Internal & Inth its external settings & Internal cohesiveness of all \\
fit & elements inside a production & Production processes, production volumes, and key \\
& system & manufacturing tasks \\
\hline
\end{tabular}

A first element in this framework involves the strategic decision concept. Empirical data show that the development team relied on the strategic decision concept to achieve information consensus. This concept was used to understand what the process innovation would achieve by specifying the company's expectations regarding the process 
innovation. The strategic decision concept complemented the corporate objective, which was considered too general for its communication across different levels of the manufacturing site despite meeting the criteria of cost, delivery, and flexibility. Therefore, information consensus was sought to transmit the purpose of the process innovation.

A second element in this framework involves the decision area concept, which the development team relied on to define what the process innovation would look like. In line with the literature (Machuca et al., 2011; Sun and Hong, 2002), empirical data show that the concepts of strategic objective and decision areas were aligned and defined the configuration of the process innovation and what it would look like. Case study data reveal that a key issue in the development of the process innovation was the realisation that the introduction of new production technologies and organisational processes was not concerned with the build-up of a new facility. Instead, the process innovation would transform the existing production system. The development team relied on the decision area concept to promote a general understanding of the existing production system and determine what issues needed to be resolved. This task was not straightforward since different perspectives existed about the operations of the existing production system and the process innovation.

The third element in this framework included the concepts of external and internal fit, which helped to solve these disagreements and determine the most critical issues affecting the operation of the process innovation. This was done in three steps. First, the development team argued that issues affecting the existing production system would also affect the process innovation. This was considered a valid argument since the process innovation would exclusively focus on new production technologies or organisational processes affecting production. Second, the most pressing concerns in the existing production system were identified. To this end, the external fit concept targeted concerns related to external settings (i.e., market changes affecting the assembly of products). In addition, the internal fit concept addressed concerns about how the process innovation would operate (e.g., concerns about the production of different product families in one assembly line). Third, the most critical issues affecting the operation of the process innovation were determined. This was achieved by comparing the existing production system to the objectives and characteristics of the process innovation. This comparison focused on findings from the external and internal fit concepts.

The use of external and internal fit concepts alone was not sufficient to achieve information consensus. This was dependent on previously consented information from the strategic objective concept, which established the inherent strengths and purpose of the process innovation. In addition, the external fit and internal fit were limited by the decision area concept. This determined what the production system would look like: a single assembly line capable of producing all products. Case study data also show that, when establishing interdependencies across these concepts, it was necessary to avoid a high level of information detail. Simplified information was preferred since the objective of information consensus was not detailing the specific operation of the process innovation but achieving agreement and pointing a way forward. The results on information consensus in relation to the pre-requisites of strategic objective, decision areas, external fit, and internal fit concepts of the case are shown in Table 5. 
Table 5 Results of information consensus in the case classified according to the concepts of strategic decision, decision areas, external fit and internal fit

\begin{tabular}{|c|c|}
\hline \multicolumn{2}{|r|}{ Strategic objective concept } \\
\hline Cost & Reduced manufacturing footprint \\
\hline Delivery & Shortened lead time to customer \\
\hline Flexibility & Common product architecture \\
\hline Quality & Not considered \\
\hline \multicolumn{2}{|r|}{ Decision areas concept } \\
\hline \multicolumn{2}{|c|}{$\begin{array}{l}\text { Single assembly line capable of producing the three existing product families on site with their } \\
600 \text { variants. Yearly volume and takt time established }\end{array}$} \\
\hline Decision area & External and Internal fit concepts \\
\hline \multicolumn{2}{|r|}{ Structural categories } \\
\hline Process technology & $\begin{array}{l}\text { Assembly sequence, main line and sub-assembly processes, } \\
\text { operations per station, handling product variation }\end{array}$ \\
\hline Capacity & Changes in product demand process innovation \\
\hline Facilities & Length of assembly stations \\
\hline Vertical integration & Not considered \\
\hline \multicolumn{2}{|r|}{ Infrastructural categories } \\
\hline Human resources & $\begin{array}{l}\text { Supporting competence development through training, work } \\
\text { instruction improvement }\end{array}$ \\
\hline Organisation & Worker assignment in assembly, meeting takt \\
\hline Quality & Current quality issues in process innovation \\
\hline $\begin{array}{l}\text { Production planning and } \\
\text { control }\end{array}$ & Developing IT system to process innovation \\
\hline New product development & $\begin{array}{l}\text { Effects of new product design and current product design } \\
\text { changes }\end{array}$ \\
\hline $\begin{array}{l}\text { Performance measurement } \\
\text { system }\end{array}$ & Assessment of process innovation benefits \\
\hline Logistics & Adapting current logistics to process innovation \\
\hline
\end{tabular}

The results of this study highlight that different perspectives about information may exist over time. This suggests that information consensus is not achieved by a single event, and active work to reduce equivocality is necessary. Specifically, we find that information consensus continuously occurs in process innovation development. This finding is not in contrast to that of Parida et al. (2017) and Stevens (2014), who target equivocality as an initial challenge of process innovation. Rather, our finding highlights the need to pursue the reduction of equivocality beyond this point. To the best of our knowledge, this finding has not been previously reported in the literature but is crucial to the introduction of innovations, as prior studies have called for iterative processing of information in the development of process innovations (Koufteros et al., 2002; Stock and Tatikonda, 2008). Accordingly, the proposed framework may help to clarify the elements of managerial concern for guiding consensus during the development of process innovations. 


\subsection{Practical implications}

The results of this study provide practical implications that may be essential for enhancing the success of process innovations at manufacturing companies. Case data suggest how the four identified pre-requisites for guiding information consensus may help reduce equivocality in process innovations.

The results of this study indicate that the concepts of strategic objective, decision areas, external fit, and internal fit are not sufficient to achieve information consensus, but their interdependency are necessary. This is crucial, as prior research has shown the importance of the linkage between different functions within a manufacturing company for successfully reducing equivocality (Lee et al., 2017; Song et al., 2007; Koufteros et al., 2005) but has not yet established what linkages are necessary to guide information consensus. This finding may be essential to avoid ineffective decisions when introducing process innovations and avert problems associated with equivocality (Eriksson et al., 2016).

Moreover, our findings suggest that not only is the linkage between the above four concepts important, but an order is indispensable to achieve information consensus when introducing new production technologies or organisational processes. Based on the case study's findings, this order would likely require establishing a purpose as an initial step, which may be achieved with the strategic decision concept. This would be followed by a clarification of what the process innovation would look like in a way that this is understood across the manufacturing company based on the decision area concept. Finally, the last step would define how the process innovation would operate defined by the external and internal fit concept.

Finally, the results of this study suggest how to use the proposed framework when guiding information consensus in the reduction of equivocality in process innovations. Case data coincide with prior studies showing that equivocality is critical in the production system design phase (Milewski et al., 2015). Therefore, manufacturing managers and development teams may find the proposed framework useful in production system design projects. Accordingly, this framework could help formalise the design work process, which is characterised by ad hoc practices (Rösiö and Bruch, 2018). In addition, the proposed framework provides a structure to detail with the pre-requisites guiding information consensus in the reduction of equivocality. This is important because prior studies indicate that development teams responsible for process innovations handle activities reactively, or fail to document commitments altogether (Kurkkio et al., 2011). Increasing the transparency of information consensus over time is important, because prior studies show that manufacturing companies reduce equivocality over time (Sjödin et al., 2016). Therefore, managers responsible for the development of process innovations may use this framework as a reference to compare prior commitments and help achieve reliable decisions in process innovations.

\section{Conclusions}

This study analysed information consensus and the reduction of equivocality in process innovations. Based on the results of a single real-time case study in the heavy vehicle industry, this study developed a novel framework to help manufacturing companies 
reduce equivocality in process innovations based on four identified pre-requisites guiding information consensus. Some key limitations of this study include its use of a single case study. Therefore, a future step would be the validation of the results through additional cases, preferably extreme cases (i.e., different conditions), to evaluate whether a rectification of the results is necessary. This study has also been limited by its focus on determining what guides information consensus. The results have shown that the concepts of strategic objective, decision areas, external and internal fit are necessary, and significant interdependencies exist. The findings of this study have not investigated the interdependencies among these concepts. Future research could determine whether these concepts hold equal importance in relation to information consensus. In line with Kurkkio et al. (2011) and Sjödin et al. (2016), we recognise that the impact of equivocality in process innovation remains understudied. To date, research efforts focused on qualitative analysis. Therefore, the use of quantitative approaches provides many opportunities for future research. We trust that the findings of this study represent a further step in understanding information consensus and confide that our results will stimulate future research focused on the reduction of equivocality in process innovations.

\section{Acknowledgements}

The authors gratefully acknowledge the contributions from all the participants from the companies in the study. Financial support from the Swedish Knowledge Foundation (KKS) to the industrial graduate school 'INNOFACTURE' is also greatly acknowledged. The study was performed in the context of the XPRES framework at Mälardalen University.

\section{References}

Bates, K.A., Amundson, S.D., Schroeder, R.G. and Morris, W.T. (1995) 'The crucial interrelationship between manufacturing strategy and organizational culture', Management Science, Vol. 41, No. 10, pp.1565-1580.

Bellgran, M. and Säfsten, K. (2010) Production Development: Design and Operation of Production Systems, Springer Science \& Business Media, New York, NY.

Berry, W.L., Klompmaker, J.E., Bozarth, C.C. and Hill, T.J. (1991) 'Factory focus: segmenting markets from an operations perspective', Journal of Operations Management, Vol. 10, No. 3, pp.363-387.

Bruch, J. and Bellgran, M. (2013) 'Characteristics affecting management of design information in the production system design process', International Journal of Production Research, Vol. 51, No. 11, pp.3241-3251.

Bryan, L. and Farrell, D. (2008) 'Leading through uncertainty', The McKinsey Quarterly, December, No. 1, pp.1-13.

Chemarin, S. and Orset, C. (2011) 'Innovation and information acquisition under time inconsistency and uncertainty', The Geneva Risk and Insurance Review, Vol. 36, No. 2, pp.132-173.

Choudhari, S.C., Adil, G.K. and Ananthakumar, U. (2010) 'Congruence of manufacturing decision areas in a production system: a research framework', International Journal of Production Research, Vol. 48, No. 20, pp.5963-5989. 
Da Silveira, G.J.C. (2005) 'Market priorities, manufacturing configuration, and business performance: an empirical analysis of the order-winners framework', Journal of Operations Management, Vol. 23, No. 6, pp.662-675.

Daft, R.L. and Lengel, R.H. (1986) 'Organizational information requirements, media richness and structural design', Management Science, Vol. 32, No. 5, pp.554-571.

Daft, R.L. and Macintosh, N.B. (1981) 'A tentative exploration into the amount and equivocality of information processing in organizational work units', Administrative Science Quarterly, Vol. 26, No. 2 pp.207-224.

Daft, R.L. and Weick, K.E. (1984) 'Toward a model of organizations as interpretation systems', Academy of Management Review, Vol. 9, No. 2, pp.284-295.

Díaz Garrido, E., Martín-Peña, M.L. and García-Muiña, F. (2007) 'Structural and infrastructural practices as elements of content operations strategy. The effect on a firm's competitiveness', International Journal of Production Research, Vol. 45, No. 9, pp.2119-2140.

Doraszelski, U. (2004) 'Innovations, improvements, and the optimal adoption of new technologies', Journal of Economic Dynamics and Control, Vol. 28, No. 7, pp.1461-1480.

Eriksson, P.E., Patel, P.C., Sjödin, D.R., Frishammar, J. and Parida, V. (2016) 'Managing interorganizational innovation projects: mitigating the negative effects of equivocality through knowledge search strategies', Long Range Planning, Vol. 49, No. 6, pp.691-705.

Frishammar, J. (2003) 'Information use in strategic decision making', Management Decision, Vol. 41, No. 4, pp.318-326.

Frishammar, J., Florén, H. and Wincent, J. (2011) 'Beyond managing uncertainty: insights from studying equivocality in the fuzzy front end of product and process innovation projects', IEEE Transactions on Engineering Management, Vol. 58, No. 3, pp.551-563.

Galbraith, J.R. (1973) Designing Complex Organizations, Addison-Wesley Longman Publishing Co., Inc., Reading, MA.

Gaubinger, K., Michael, R., Swan, S. and Werani, T. (2014) Innovation and Product Management: A Holistic and Practical Approach to Uncertainty Reduction, Springer, Berlin, Heidelberg.

Gino, F. and Pisano, G. (2008) 'Toward a theory of behavioral operations', Manufacturing \& Service Operations Management, Vol. 10, No. 4, pp.676-691.

Harris, E. and Woolley, R. (2009) 'Facilitating innovation through cognitive mapping of uncertainty', International Studies of Management \& Organization, Vol. 39, No. 1, pp.70-100.

Hayes, R., Pisano, G., Upton, D. and Wheelwright, S.C. (2004) Operations, Strategy, and Technology: Pursuing the Competitive Edge, John Wiley \& Sons, Indianapolis, IN.

Hayes, R.H. and Wheelwright, S.C. (1984) Restoring Our Competitive Edge: Competing through Manufacturing, John Wiley \& Sons, New York, NY.

Jalonen, H. (2011) 'The uncertainty of innovation: a systematic review of the literature', Journal of Management Research, Vol. 4, No. 1, pp.1-47.

Karlsson, C. (2010) Researching Operations Management, Routledge, New York, NY.

Koufteros, X., Vonderembse, M. and Jayaram, J. (2005) 'Internal and external integration for product development: the contingency effects of uncertainty, equivocality, and platform strategy', Decision Sciences, Vol. 36, No. 1, pp.97-133.

Koufteros, X.A., Vonderembse, M.A. and Doll, W.J. (2002) 'Integrated product development practices and competitive capabilities: the effects of uncertainty, equivocality, and platform strategy', Journal of Operations Management, Vol. 20, No. 4, pp.331-355.

Kurkkio, M., Frishammar, J. and Lichtenthaler, U. (2011) 'Where process development begins: a multiple case study of front end activities in process firms', Technovation, Vol. 31, No. 9, pp.490-504.

Lee, J.Y., Swink, M. and Pandejpong, T. (2017) 'Team diversity and manufacturing process innovation performance: the moderating role of technology maturity', International Journal of Production Research, Vol. 55, No. 17, pp.4912-4930. 
Liu, R. and Hart, S. (2011) 'Does experience matter? A study of knowledge processes and uncertainty reduction in solution innovation', Industrial Marketing Management, Vol. 40, No. 5, pp.691-698.

Machuca, J.A.D., Ortega Jiménez, C.H., Garrido-Vega, P.M. and De Los Ríos, J.L.P.D. (2011) 'Do technology and manufacturing strategy links enhance operational performance? Empirical research in the auto supplier sector', International Journal of Production Economics, Vol. 133, No. 2, pp.541-550.

Marzi, G., Dabić, M., Daim, T. and Garces, E. (2017) 'Product and process innovation in manufacturing firms: a 30-year bibliometric analysis', Scientometrics, Vol. 113, No. 2, pp.673-704.

McCutcheon, D.M. and Meredith, J.R. (1993) 'Conducting case study research in operations management', Journal of Operations Management, Vol. 11, No. 3, pp.239-256.

Miles, M.B., Huberman, A.M. and Saldaña, J. (2013) Qualitative Data Analysis: A Methods Sourcebook, Sage Publications, Thousand Oaks, CA.

Milewski, S.K., Fernandes, K.J. and Mount, M.P. (2015) 'Exploring technological process innovation from a lifecycle perspective', International Journal of Operations \& Production Management, Vol. 35, No. 9, pp.1312-1331.

Miller, D. (1992) 'Environmental fit versus internal fit', Organization Science, Vol. 3, No. 2, pp.159-178.

Miltenburg, J. (2005) Manufacturing Strategy: How to Formulate and Implement a Winning Plan, Productivity Press, Portland, Oregon.

Mintzberg, H., Raisinghani, D. and Théorêt, A. (1976) 'The structure of 'unstructured' decision processes', Administrative Science Quarterly, Vol. 21, No. 2, pp.246-275.

Montoya-Weiss, M.M. and O'Driscoll, T.M. (2000) 'From experience: applying performance support technology in the fuzzy front end', Journal of Product Innovation Management, Vol. 17, No. 2, pp.143-161.

Nair, A. and Boulton, W.R. (2008) 'Innovation-oriented operations strategy typology and stage-based model', International Journal of Operations \& Production Management, Vol. 28, No. 8, pp.748-771.

O'Connor, G.C. and Rice, M.P. (2013) 'A comprehensive model of uncertainty associated with radical innovation', Journal of Product Innovation Management, Vol. 30, No. 1, pp.2-18.

Olhager, J. (1993) 'Manufacturing flexibility and profitability', International Journal of Production Economics, Vols. 30-31, pp.67-78.

Parida, V., Patel, P.C., Frishammar, J. and Wincent, J. (2017) 'Managing the front-end phase of process innovation under conditions of high uncertainty', Quality \& Quantity, Vol. 51, No. 5, pp.1983-2000.

Petrick, I.J. and Provance, M. (2005) 'Roadmapping as a mitigator of uncertainty in strategic technology choice', International Journal of Technology Intelligence and Planning, Vol. 1, No. 2, pp.171-184.

Piening, E.P. and Salge, T. O. (2015) 'Understanding the antecedents, contingencies, and performance implications of process innovation: a dynamic capabilities perspective', Journal of Product Innovation Management, Vol. 32, No. 1, pp.80-97.

Pisano, G.P. (1997) The Development Factory: Unlocking the Potential of Process Innovation, Harvard Business Press, Boston, MA.

Porter, M.E. (1985) 'Technology and competitive advantage', Journal of Business Strategy (pre-1986), Vol. 5, No. 3, pp.60-78.

Ramasesh, R.V. and Browning, T.R. (2014) 'A conceptual framework for tackling knowable unknown unknowns in project management', Journal of Operations Management, Vol. 32, No. 4, pp.190-204.

Reichstein, T. and Salter, A. (2006) 'Investigating the sources of process innovation among UK manufacturing firms', Industrial and Corporate Change, Vol. 15, No. 4, pp.653-682. 
Rösiö, C. and Bruch, J. (2018) 'Exploring the design process of reconfigurable industrial production systems: activities, challenges, and tactics', Journal of Manufacturing Technology Management, Vol. 29, No. 1, pp.85-103.

Säfsten, K., Johansson, G., Lakemond, N. and Magnusson, T. (2014) 'Interface challenges and managerial issues in the industrial innovation process', Journal of Manufacturing Technology Management, Vol. 25, No. 2, pp.218-239.

Sjödin, D.R., Frishammar, J. and Eriksson, P.E. (2016) 'Managing uncertainty and equivocality in joint process development projects', Journal of Engineering and Technology Management, January, Vol. 39, No. 1, pp.13-25.

Skinner, W. (1969) 'Manufacturing-missing link in corporate strategy', Harvard Business Review, Vol. 47, No. 3, pp.136-145.

Slack, N. and Lewis, M. (2002) Operations Strategy, Pearson Education Limited, Harlow, Essex.

Song, Y-I., Lee, D-H., Lee, Y-G. and Chung, Y-C. (2007) 'Managing uncertainty and ambiguity in frontier R\&D projects: a Korean case study', Journal of Engineering and Technology Management, Vol. 24, No. 3, pp.231-250.

Soosay, C., Nunes, B., Bennett, D.J., Sohal, A., Jabar, J. and Winroth, M. (2016) 'Strategies for sustaining manufacturing competitiveness: comparative case studies in Australia and Sweden', Journal of Manufacturing Technology Management, Vol. 27, No. 1, pp.6-37.

Stevens, E. (2014) 'Fuzzy front-end learning strategies: exploration of a high-tech company', Technovation, Vol. 34, No. 8, pp.431-440.

Stock, G.N. and Tatikonda, M.V. (2008) 'The joint influence of technology uncertainty and interorganizational interaction on external technology integration success', Journal of Operations Management, Vol. 26, No. 1, pp.65-80.

Sun, H. and Hong, C. (2002) 'The alignment between manufacturing and business strategies: its influence on business performance', Technovation, Vol. 22, No. 11, pp.699-705.

Sutcliffe, K.M. (1994) 'What executives notice: accurate perceptions in top management teams', Academy of Management Journal, Vol. 37, No. 5, pp.1360-1378.

Tatikonda, M.V. and Montoya-Weiss, M.M. (2001) 'Integrating operations and marketing perspectives of product innovation: the influence of organizational process factors and capabilities on development performance', Management Science, Vol. 47, No. 1, pp.151-172.

Voss, C., Tsikriktsis, N. and Frohlich, M. (2002) 'Case research in operations management', International Journal of Operations \& Production Management, Vol. 22, No. 2, pp.195-219.

Ward, P.T., Mccreery, J.K. and Anand, G. (2007) 'Business strategies and manufacturing decisions: an empirical examination of linkages', International Journal of Operations \& Production Management, Vol. 27, No. 9, pp.951-973.

Weick, K.E. (1995) Sensemaking in Organizations, Sage, Thousand Oaks, CA.

Yin, R.K. (2013) Case Study Research: Design and Methods, 5th ed., Sage Publications, Thousand Oaks, CA.

Yin, Y., Stecke, K.E., Swink, M. and Kaku, I. (2017) 'Lessons from seru production on manufacturing competitively in a high cost environment', Journal of Operations Management, Vol. 49-51, No. 1, pp.67-76.

Zack, M.H. (2001) 'If managing knowledge is the solution, then what's the problem?', in Malhotra, Y. (Ed.): Knowledge Management and Business Model Innovation, Idea Group Publishing, Hershey, PA. 